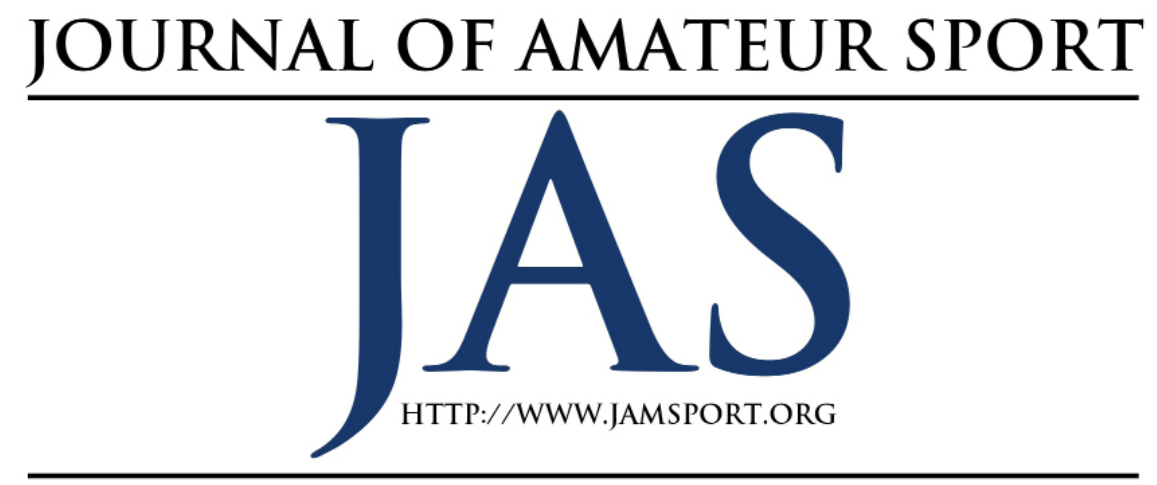

\title{
Constraints and Negotiations to Student Recreational Sport Center Usage
}

\author{
Samantha L. Powers ${ }^{1}$ \\ Robert J. Barcelona ${ }^{3}$ \\ Nate E. Trauntvein ${ }^{2}$ \\ Cindy L. Hartman ${ }^{3}$ \\ ${ }^{1}$ Pennsylvania State University \\ ${ }^{2}$ Utah State University \\ ${ }^{3}$ University of New Hampshire
}

\begin{abstract}
Studies have shown that student recreational sports centers (SRSCs) offer a variety of benefits to emerging adult students. Previous research has identified the presence of constraints to physical activity and SRSC usage (Flood \& Parker, 2014; Stankowski, Trauntvein, \& Hall, 2017; Young, Ross, \& Barcelona, 2003). However, little research has examined the negotiation strategies which students use to increase their physical activity levels through use of the SRSC. This study focused on the constraints and negotiation strategies which affected both users and infrequent users of the SRSC at a mid-size, public university in the northeastern United States. Results suggested that constraints and negotiation strategies differed significantly between user groups and that several constraints and negotiations predict frequency of visitation to the SRSC. Findings suggest the importance of management actions which help students to create social networks, improve their planning and prioritization, and develop self-efficacy with regard to physical activity at the SRSC.
\end{abstract}

\section{Introduction}

$\mathrm{E}$ merging adulthood, the developmental life phase associated with the traditional college student years (i.e., 18-25 years old), is a crucial time for the development of health-re- lated attitudes and behaviors (Nelson, Story, Larson, Neumark-Sztainer, \& Lytle, 2008). During this life phase, college students are afforded the opportunity to explore and commit to values, behaviors, identities, and relationships 
(Arnett, 2014). The variety of experiences available to students, and the lack of prescribed pathways on how to navigate them may create adaptive and maladaptive forms of physical and mental health among college students (ACHA NCHAII Full Report, 2016).

Overall, the physical and mental health of college students is concerning (ACHA NCHA-II Full Report, 2016). Research has repeatedly identified the benefits of physical activity upon both physical and mental health, yet students' participation in physical activity is notably below the recommended weekly guidelines (ACHA NCHA-II Full Report, 2016). Student Recreational Sport Centers (SRSCs) provide on-campus opportunities for students to be physically active, yet students often do not visit these facilities as much as they would like to (Stankowski et al., 2017). In order to better manage SRSCs and their associated programs with the goal of increasing student physical activity, we need to understand not only students' use of these facilities, but also reasons why they may not use them as much as they would like as well as how they negotiate these reasons. Understanding these complexities would allow SRSCs to better assist students in negotiating barriers to visiting their facilities, and in turn, could increase student levels of physical activity. The college years are an important time for the development of health and well-being habits that will affect college students on campus and beyond (Nelson et al., 2008). SRSCs can help to encourage development of healthy hab- its through increasing student access to physical activity. This study examined the pattern of constraints experienced by college students and the negotiation strategies they engage in when using the SRSC on campus.

\section{Literature Review}

\section{Student Recreational Sport Centers}

SRSCs offer a variety of facilities and programming for college students to be physically active. Use of SRSCs and participation in collegiate recreational sports has been linked to a variety of positive outcomes. Research suggests that students who frequently use SRSCs benefit from positive physical and mental health outcomes, higher retention rates and academic performance, overall positive wellbeing, and a stronger sense of community (Danbert, Pivarnik, McNeil, \& Washington, 2014; Elkins, Beggs, \& Choutka, 2007; Forrester, 2017; Hall, 2006; Huesman, Brown, Lee, Kellogg, \& Radcliffe, 2009; Kampf \& Teske, 2013; Kim, Sparvero, \& Olmeda, 2016). However, despite the benefits of SRSCs, many students do not visit these facilities as often as they would like (Stankowski, Trauntvein, \& Hall, 2017; Young, Ross, \& Barcelona, 2003).

\section{Student Health}

The current physical and mental health profiles of college students are concerning. Physically, over one-third of college students are classified as overweight or obese (ACHA NCHA-II Executive Summary, 2016). Students' psycho- 
logical health (i.e., mental and emotional health) is also a concern. Approximately $85 \%$ of students report that they have felt overwhelmed by all they had to do over the last 12 months and more than $54 \%$ of students reported feeling more than average or tremendous stress over the last 12 months (ACHA NCHA-II Full Report, 2016). Researchers have pointed to physical activity as a potential solution in addressing the physical and psychological health outcomes of college students, as students who meet vigorous physical activity recommendations are less likely to report poor mental health outcomes and perceived stress (VanKim \& Nelson, 2013). Moreover, physical activity may act as a protective factor in that students who engage in vigorous physical activity behaviors are more likely to exhibit high levels of stress tolerance (Bland, Melton, Bigham, \& Welle, 2014).

SRSCs offer students a variety of activities and options to be physically active and improve their overall wellbeing. Not only can SRSCs benefit individuals, but in partnership with student health and counseling centers, they can help address issues related to student health and wellness on campus (Fullerton, 2010; Hartman, Evans, Barcelona, \& Brookover, 2018). For example, some universities have health and wellness satellite offices within their SRSCs (e.g., University of New Hampshire's THRIVE) or even have combined departments (e.g., Elon University's Campus Recreation \& Wellness). Furthermore, studies have shown that students who use SRSCs have better academic performance and may also remain more connected with the university through continued enrollment (Danbert et al., 2014; Kampf \& Teske, 2013).

Despite the physical and psychological health benefits of physical activity as well as the availability of SRSCs, the majority of college students fail to be physically active and/or meet the physical activity guidelines during their college tenure (Racette, Deusinger, Strube, Highstein, \& Dusinger, 2008; Small, Bailey-Davis, Morgan, \& Maggs, 2013). The weekly recommended amount of physical activity for adults includes a minimum of 150 minutes of moderate-intensity aerobic activity and at least two days engaging in muscle-strengthening activities that work all major muscle groups (Centers for Disease Control and Prevention, 2017). Less than half of all college students report meeting the recommendations for moderate-intensity exercise and approximately $62 \%$ of students report they do not meet the weekly recommended amounts and repetitions of strength training exercises (ACHA NCHA-II Full Report, 2016). Because many students do not complete the recommended levels of physical activity, they may not be receiving the associated physical and psychological health benefits that physical activity provides.

There are several psychosocial factors that may explain why students may or may not meet the recommended levels of physical activity and therefore may not realize the general health benefits of physical activity. Likewise, these psycho- 
social factors may explain why students may not utilize the SRSC as a resource to facilitate being physically active. This study focused on two psychosocial factors: perceived constraints to physical activity and the negotiation skills which mediate those constraints.

\section{Perceived Constraints to Physical Activity and SRSC Usage}

Despite desires to be more physically active, many students report that they do not visit the SRSC or other fitness destinations as much as they would like due to a variety of constraints (Stankowski et al., 2017). Perceived constraints limit or negate physical activity participation and can often be categorized into the following hierarchical themes: intrapersonal, interpersonal, and structural (Crawford, Jackson, \& Godbey, 1991; Stankowski et al., 2017; Young et al., 2003). Intrapersonal constraints generally relate to feelings of physical and psychological safety including a lack of skills or confidence, whereas interpersonal constraints refer to social interactions such as a lack of people with whom to be physically active or visit the recreation center (Stankowski et al., 2017; Young et al., 2003). Structural constraints may relate to issues of time and available information about being physically active and places to do so. Issues with facilities and their management can also be structural constraints; for example, these can include crowding, perceptions of the environment, and transportation, among others. Crawford et al.'s (1991) hierarchical model of lei- sure constraints suggests that individuals must first negotiate intrapersonal constraints, followed by interpersonal, and then structural.

While it is important that campus recreation professionals understand all of the constraints that college students perceive as hindering their use of SRSCs, structural constraints are often the ones that are most easily addressed (Stankowski et al., 2017). For example, time remains a major constraint to physical activity for people of all ages (Young et al., 2003) as college students often perceive that they do not have enough time or have other obligations that interfere with being physically active (Stankowski et al., 2017). Common structural constraints to SRSC participation which relate directly to facility management could include the perception of an unwelcoming atmosphere, non user-friendly hours, or a lack of desirable activities. All of these can be directly addressed by campus recreation professionals.

\section{Negotiation Strategies}

Constraints exist in all forms of leisure, but not all who experience constraints cease participation in leisure activities. Constraint negotiation strategies provide an avenue for people to reframe their leisure experiences and alter or increase their participation rather than eliminate it (Jackson, Crawford, \& Godbey, 1993). In terms of leisure related to physical activity, negotiation strategies could help college students increase their physical activity levels as well as usage of 
the SRSC. While little research has been done in this specific area, Elkins et al. (2007) investigated the role of physical activity constraint negotiation strategies in leisure satisfaction among college students. Their results suggest that college students most commonly use physical activity negotiation strategies related to interpersonal relations and developing new skills. Furthermore, they suggest that "the strongest predictors of leisure satisfaction are negotiation strategies which involve a social component, the practicing of a skill in order to improve, and a sense of accomplishment during participation" (Elkins et al., 2007, p. 107). Thus, constraint negotiation strategies may play an important role in physical activity participation and likewise, in leisure satisfaction for college students (Elkins et al., 2007).

This study examined negotiation strategies which related to the three categories of physical activity constraints as described by Crawford, Jackson, and Godbey (1991). In terms of interpersonal relations, this study investigated how the social support of friends, family, and recreation center employees can help students overcome perceived barriers. Additionally, for negotiations related to fitness and skill development, this research examined intrapersonal constraints including student's levels of self-efficacy as well as confidence in areas of physical activity. Lastly, we explored students' use of negotiation strategies related to structural constraints including the management of the SRSC.

\section{Research Questions}

While many campus recreation studies have focused on the role of constraints to physical activity (e.g., Flood \& Parker, 2014; Stankowski et al., 2017; Young et al., 2003) few have examined how constraints to physical activity and constraint negotiation strategies relate to general physical activity and SRSC usage. The purpose of this research was to determine the extent to which psychosocial factors related to physical activity constraints and negotiations to SRSC usage among college students. The research questions included:

1. Is there a significant difference in perceived constraints between users and infrequent users of the SRSC?

2. Is there a significant difference in the constraint negotiations used by users and infrequent users of the SRSC?

3. Which perceived constraints and negotiation strategies, if any, predict or relate to frequency of use of the SRSC?

\section{Methods}

This study ( $\mathrm{n}=419)$ used a cross sectional quantitative survey to collect data at a public, Land Grant, residential research university with an enrollment of approximately 15,000 students located in rural town in the northeastern United States. An initial pilot survey was conducted using an entry level general education social science class to assess the quality and readability of the survey 
items. The pilot survey was completed by 74 undergraduate students. An online (Qualtrics) questionnaire was distributed to a stratified random sample of 2,750 of 15,398 students enrolled at the university in the Spring of 2016. The sample was stratified equally by class year and included graduate students. Students in their fourth year and beyond were oversampled to account for students who did not graduate in four years. The selected sample was emailed a link to the questionnaire a total of three times using a modified Dillman method (Dillman, Smyth, \& Christian, 2009). Four hundred and nineteen $(\mathrm{n}=419)$ respondents completed the survey with enough data for analysis resulting in a response rate of $15.2 \%$. Each portion of this study was approved by the university's Institutional Review Board for the Protection of $\mathrm{Hu}-$ man Subjects in Research.

\section{Student Recreational Sports Center (SRSC)}

This study focused primarily on students' use and perceptions of the SRSC on campus. The SRSC was originally built in 1995 as part of a renovation to an existing athletics facility on campus; the facility was renovated again in 2016, and now encompasses the following: over 18,000 square feet of fitness space with free weights, selectorized machines, cardo equipment and stretching areas; six athletic courts; an indoor jogging track; two fitness studios; an indoor cycling/ spin studio; three racquetball and squash courts; a demonstration kitchen; an 850 square foot indoor climbing wall; classrooms; and meeting space. An outdoor lap pool, diving well, and zero-entry leisure pool is adjacent to the building. The facility hosts a variety of campus recreational sports programs, including fitness classes, intramural sports, sport clubs, instructional programs, academic classes, and drop-in recreation. The SRSC is located in the central campus core, within walking distance from most of the academic and residence halls, and is located on the University's bus line. The facility is open to all undergraduate and graduate students on campus, and is funded primarily through student activity fees assessed as part of student tuition bills each semester. The SRSC is open for university faculty, staff, and residents of the local community after paying a separate membership fee.

\section{Instrument}

Respondents took approximately 15 minutes to complete this survey which included measures of SRSC usage, constraints to physical activity, physical activity constraint negotiations, and demographics. Respondents were asked how often they used the SRSC and were then classified into dichotomous groups of users and infrequent users. Respondents who reported visiting the SRSC less than once per month were classified as infrequent users. Leisure time activity constraints and negotiation measures were adapted from Son, Mowen, and Kerstetter (2008). 
The constraint items were measured on five-point Likert scales, ranging from $1=$ strongly disagree to $5=$ strongly agree. The negotiation items were measured on five-point Likert scales, ranging from $1=$ never to $5=$ always. Using an exploratory factor analysis with a varimax rotation, the 25 leisure time activity constraint items factored into five domains (time, $\alpha=.62$; management, $\alpha=.73$; social support, $\alpha=.75$; self-efficacy, $\alpha$ $=.86$; transportation, $\alpha=.64$; safe environment, $\alpha=.83$ ). Using an exploratory factor analysis with a varimax rotation the 20 leisure time activity constraints negotiation items factored into four domains (financial, $\alpha=.73$; planning and prioritization, $\alpha=.79$; psychological reframing, $\alpha=.72$; social, $\alpha=.81$; recreation center assisted, $\alpha=.59)$. Internal consistency tests showed strong evidence of reliability for all constraints and negotiation constructs, with the exception of "recreation assisted" negotiation (DeVellis, 1991). Two negotiation items did not factor into domains, but remained strong on their own: "I cut short my physical activity session" and "I substitute a more convenient activity for a preferred one."

\section{Analysis}

Data were analyzed in SPSS Version 24. Descriptive statistics were used to describe the sample with regard to demographics and visitation to the SRSC. One-way analysis of variance was used to examine differences between SRSC users and infrequent users in the ideal number of visits to the SRSC as well as con- straints and negotiation strategies. Stepwise multiple linear regression was used to develop a path model of constraints and negotiation constructs related to frequency of SRSC visitation among all respondents (i.e., both users and infrequent users).

\section{Results}

\section{Demographics}

Of the respondents, 290 (62.4\%) were female and 174 were male $(37.4 \%)$. The percent of female respondents in this study was higher than the percent of enrolled female students (55\% of all university students). Respondents ranged in age from 18 to 61 years old, with an average age of $23(S D=5.7)$. There was a fairly equal distribution of respondents between the freshman, sophomore and junior classes $(22.5 \%, 22.9 \%, 19.1 \%$, respectively). There was a notable decrease in the number of respondents from the senior class (14.4\%) compared to the other classes. Masters students and Ph.D. students represented $12.8 \%$ and $7.3 \%$ of the respondents, respectively (Table 1).

\section{SRSC Visitation}

Respondents reported visiting the SRSC an average of $8.1(S D=8.9)$ times per month, but $71.6 \%$ of respondents said that they do not visit the SRSC as often as they would like. Seventy-five percent of respondents were considered users and $25 \%$ were infrequent users. Statistically significant differences were found between user and infrequent user groups in regard to ideal number of vis- 
its per month $(M=21.1, S D=8.0 ; M=8.5, \quad$ ity. Constraint domains related to Time $S D=7.6 ; p<.001$, respectively). $(F(1,417)=4.67, p<.05)$, Social Support $(F(1,417)=12.79, p<.001)$, and Self-Effi-

Bivariate Analysis of Constraints Between Users and Infrequent Users

Respondents identified a variety of constraint domains which inhibited their ability to be physically active at the SRSC. There were several constraints which suggested that users and infrequent users differed significantly in their perception of barriers to physical activ$\operatorname{cacy}(F(1,417)=21.73, p<.001)$ were significantly different between users and infrequent users. Infrequent users reported significantly higher constraints than users relative to Time $(M=3.38, S D=1.07$; $M=3.14, S D=1.10$, respectively), Social Support $(M=2.51, S D=.78 ; M=2.21$, $S D=.83$, respectively), and Self-Efficacy $(M=2.40, S D=.99 ; M=1.96, S D=.90$, respectively).

Table 1

Demographics and Visitor Use

\begin{tabular}{|c|c|c|}
\hline Variable & $\%$ or Mean & $n$ \\
\hline Age & $M=22.9(S D=5.7)$ & 419 \\
\hline $18-19$ & $14.6 \%$ & 62 \\
\hline 20 & $21.7 \%$ & 91 \\
\hline 21 & $22.2 \%$ & 93 \\
\hline 22 & $13.4 \%$ & 56 \\
\hline 23 & $7.9 \%$ & 33 \\
\hline 24 and older & $20 \%$ & 84 \\
\hline \multicolumn{3}{|l|}{ Class } \\
\hline First Year Undergraduate & $22.5 \%$ & 95 \\
\hline Second Year Undergraduate & $22.9 \%$ & 97 \\
\hline Third Year Undergraduate & $19.1 \%$ & 81 \\
\hline Fourth Plus Year Undergraduate & $14.4 \%$ & 61 \\
\hline M.S. & $12.8 \%$ & 54 \\
\hline Ph.D. & $7.3 \%$ & 31 \\
\hline \multicolumn{3}{|l|}{ Gender } \\
\hline Male & $37.4 \%$ & 174 \\
\hline Female & $62.4 \%$ & 290 \\
\hline & Average number of visits per month & 419 \\
\hline \multicolumn{3}{|l|}{ Do you visit as often as you would like? } \\
\hline Yes & $28.4 \%$ & 120 \\
\hline No & $71.6 \%$ & 303 \\
\hline \multicolumn{2}{|l|}{ Optimal number of visits per month } & 412 \\
\hline
\end{tabular}


In terms of individual items, infrequent users were significantly more likely to report not having enough time to be physically active $(p<.001)$; not feeling welcome $(p<.001)$; having no one to be physically active with $(p<.001)$; lacking support for physical activity from friends and family $(p<.01)$; and having friends who do not have the time to be physically active $(p<.05)$. Finally, all of the Self-Efficacy items were significantly different, with infrequent users reporting higher constraints in the following: not having enough physical energy $(\phi<.001)$; being intimidated by physical activity environments $(p<.001)$; not liking being physically active $(p<.001)$; feeling self-conscious about their body $(p<.001)$; and not being in good enough shape $(p<.01)$. A list of all constraint domains and individual items can be found in Table 2 .

\section{Bivariate Analysis of Constraint Negotiation Strategies Between Users and Infrequent Users}

Users and infrequent users both utilized a variety of negotiation strategies to overcome constraints to being physically active at the SRSC. Both users and infrequent users reported financial negotiations as their most frequently used strategy. The types of strategies implemented differed significantly between users and infrequent users with regard to Planning and Prioritization $(F(1,417)=53.078$, $p<.001)$, Social $(F(1,417)=37.257$, $p<.001)$, and Recreation Center Assisted negotiation domains $(F(1,415)=30.960$, $p<.001)$.

Users were significantly more likely than infrequent users to utilize Planning and Prioritization negotiations $(M=3.63$, $S D=.52 ; M=3.22, S D=.63$, respectively). It is interesting to note that only one item within the domain ("I try to plan ahead in order to be physically active") was significant on its own $(p<.001)$, suggesting that use of this negotiation item strongly differentiated users and infrequent users. Users were also significantly more likely to engage in Social $(M=3.32$, $S D=.82 ; M=2.78, S D=.94$, respectively) and Recreation Center Assisted negotiations $(M=1.89, S D=.70 ; M=1.51$, $S D=.63$, respectively). Infrequent users were significantly less likely than users to utilize each of strategies within the Recreation Center Assisted negotiation domain: talking to recreation center personnel $(p<.001)$, arranging rides to the recreation center with friends $(p<.001)$, and expressing anger to the person who caused a conflict situation in the recreation center $(p<.05)$.

\section{Constraints, Negotiations, and Frequency of Use}

A majority of survey respondents reported that they desired to visit the SRSC more frequently, but they encountered constraints that prevented their visitation. To assess which constraints posed the strongest barriers to visitation and which negotiations mediated these barriers, all constraints and negotiations were 
Table 2

One-Way Analysis of Variance Comparing Mean Respondent Constraint Scores by Frequency of Use

\begin{tabular}{|c|c|c|c|c|c|c|}
\hline Constraint ${ }^{a}$ & $\mathbf{N}$ & $\begin{array}{l}\text { Overall } \\
\text { Meann }^{\text {b }} \\
(S D)\end{array}$ & $\begin{array}{l}\text { User } \\
\text { Mean }^{\text {b }} \\
(S D)\end{array}$ & $\begin{array}{c}\text { Infrequent } \\
\text { User } \\
\text { Mean }^{\mathrm{b}} \\
(S D)\end{array}$ & $F$ & $p$ \\
\hline Time $(\alpha=.620)$ & 419 & $3.21(1.11)$ & $3.14(1.10)$ & $3.38(1.07)$ & 4.667 & .031 \\
\hline $\begin{array}{l}\text { I do not have enough time } \\
\text { to be physically active. }\end{array}$ & 418 & $3.20(1.32)$ & $3.01(1.32)$ & $3.53(1.26)$ & 15.230 & $.000^{*}$ \\
\hline $\begin{array}{l}\text { I would be physically active } \\
\text { if I didn't have so many } \\
\text { other social obligations. }\end{array}$ & 418 & $3.26(1.27)$ & $3.28(1.24)$ & $3.24(1.32)$ & .103 & .749 \\
\hline Management $(\alpha=.725)$ & 419 & $2.36(81)$ & $2.34(1.94)$ & $2.41(.84)$ & .685 & .408 \\
\hline $\begin{array}{l}\text { I don't feel welcome at the } \\
\text { recreation center. }\end{array}$ & 419 & $1.87(1.11)$ & $1.72(1.06)$ & $2.13(1.15)$ & 13.061 & $.000^{*}$ \\
\hline $\begin{array}{l}\text { Places to be physically active } \\
\text { are too crowded. }\end{array}$ & 418 & $3.53(1.37)$ & $3.63(1.34)$ & $3.37(1.40)$ & 3.361 & .067 \\
\hline $\begin{array}{l}\text { My recreation center does } \\
\text { not offer the activities I } \\
\text { want. }\end{array}$ & 418 & $2.27(1.13)$ & $2.21(1.14)$ & $2.37(1.12)$ & 1.861 & .173 \\
\hline $\begin{array}{l}\text { The recreation center is } \\
\text { closed when I want to visit. }\end{array}$ & 418 & $1.89(1.12)$ & $1.86(1.14)$ & $1.94(1.09)$ & .479 & .489 \\
\hline $\begin{array}{l}\text { The maintenance of the } \\
\text { recreation center is poor. }\end{array}$ & 418 & $2.26(1.12)$ & $2.28(1.15)$ & $2.23(1.07)$ & .239 & .625 \\
\hline Social Support $(\alpha=.753)$ & 419 & $2.31(.81)$ & $2.21(.83)$ & $2.51(.78)$ & 12.793 & $.000 *$ \\
\hline $\begin{array}{l}\text { I have no one to be } \\
\text { physically active with. }\end{array}$ & 419 & $2.32(1.28)$ & $2.09(1.21)$ & $2.73(1.292)$ & 25.554 & $.000 *$ \\
\hline $\begin{array}{l}\text { I lack support for physical } \\
\text { activity from friends and } \\
\text { family. }\end{array}$ & 417 & $1.78(1.03)$ & $1.68(.99)$ & $1.97(1.08)$ & 7.839 & $.005^{*}$ \\
\hline $\begin{array}{l}\text { My friends don't have time } \\
\text { to be physically active. }\end{array}$ & 418 & $2.58(1.12)$ & $2.50(1.10)$ & $2.74(1.14)$ & 4.349 & $.038^{*}$ \\
\hline $\begin{array}{l}\text { My friends' skill levels are } \\
\text { different than mine. }\end{array}$ & 418 & $2.94(1.24)$ & $2.86(1.27)$ & $3.07(1.19)$ & 2.633 & .105 \\
\hline $\begin{array}{l}\text { I am not physically active } \\
\text { because my friends prefer } \\
\text { other activities. }\end{array}$ & 419 & $1.97(1.05)$ & $1.93(1.04)$ & $2.05(1.06)$ & 1.348 & .246 \\
\hline Self-Efficacy $(\alpha=.855)$ & 419 & $2.10(.93)$ & $1.96(.90)$ & $2.40(.99)$ & 21.733 & $.000^{*}$ \\
\hline $\begin{array}{l}\text { I do not have enough } \\
\text { physical energy to be } \\
\text { physically active. }\end{array}$ & 419 & $2.51(1.34)$ & $2.33(1.29)$ & $2.84(1.35)$ & 14.362 & $.000 *$ \\
\hline $\begin{array}{l}\text { I am intimidated by physical } \\
\text { activity environments. }\end{array}$ & 418 & $2.42(1.35)$ & $2.20(1.28)$ & $2.79(1.40)$ & 19.003 & $.000^{*}$ \\
\hline
\end{tabular}

Journal of Amateur Sport $\quad$ Volume Five, Issue Two $\quad$ Powers et al., $2019 \quad 27$ 
Table 2 (continued)

One-Way Analysis of Variance Comparing Mean Respondent Constraint Scores by Frequency of Use

\begin{tabular}{|c|c|c|c|c|c|c|}
\hline Constraint $^{\mathrm{a}}$ & $\mathbf{N}$ & $\begin{array}{l}\text { Overall } \\
\text { Mean }^{\mathrm{b}} \\
(S D)\end{array}$ & $\begin{array}{l}\text { User } \\
\text { Mean }^{\mathrm{b}} \\
(S D)\end{array}$ & $\begin{array}{l}\text { Infrequent } \\
\text { User } \\
\text { Mean }^{\text {b }} \\
\text { (SD) }\end{array}$ & $F$ & $p$ \\
\hline $\begin{array}{l}\text { I don't like to be physically } \\
\text { active. }\end{array}$ & 419 & $1.65(1.03)$ & $1.46(.86)$ & $1.99(1.20)$ & 26.731 & $.000^{*}$ \\
\hline $\begin{array}{l}\text { I feel self-conscious about } \\
\text { my body when I am } \\
\text { physically active. }\end{array}$ & 419 & $2.43(1.41)$ & $2.26(1.33)$ & $2.73(1.51)$ & 10.878 & $.001 *$ \\
\hline $\begin{array}{l}\text { I am not in good enough } \\
\text { shape to be physically active. }\end{array}$ & 419 & $1.88(1.18)$ & $1.77(1.11)$ & $2.08(1.27)$ & 6.672 & $.010^{*}$ \\
\hline Transportation $(\alpha=.640)$ & 419 & $1.99(.96)$ & $1.94(.95)$ & $2.07(.99)$ & 1.635 & .202 \\
\hline $\begin{array}{l}\text { The places to be physically } \\
\text { active are too far from my } \\
\text { home. }\end{array}$ & 419 & $2.27(1.24)$ & $2.19(1.19)$ & $2.41(1.31)$ & 3.161 & .076 \\
\hline $\begin{array}{l}\text { I don't have adequate } \\
\text { transportation to the places } \\
\text { to be physically active. }\end{array}$ & 419 & $1.70(1.00)$ & $1.69(1.01)$ & $1.72(.98)$ & .076 & .784 \\
\hline Safe Environment $(\alpha=.833)$ & 419 & $1.52(.69)$ & $1.51(.69)$ & $1.54(.60)$ & .144 & .705 \\
\hline $\begin{array}{l}\text { I do not have enough } \\
\text { information on } \\
\text { opportunities for physical } \\
\text { activity. }\end{array}$ & 415 & $1.84(1.05)$ & $1.76(1.02)$ & $1.96(1.08)$ & 3.463 & .063 \\
\hline $\begin{array}{l}\text { I fear that others might hurt } \\
\text { me during physical activity. }\end{array}$ & 418 & $1.45(.87)$ & $1.40(.84)$ & $1.55(.92)$ & 2.820 & .094 \\
\hline $\begin{array}{l}\text { I think I might get injured } \\
\text { when being physically active. }\end{array}$ & 419 & $1.81(1.05)$ & $1.76(1.05)$ & 1.89 (1.04) & 1.573 & .211 \\
\hline $\begin{array}{l}\text { My cultural beliefs restrict } \\
\text { me from being physically } \\
\text { active. }\end{array}$ & 417 & $1.27(.70)$ & $1.30(.78)$ & $1.23(.53)$ & .939 & .334 \\
\hline $\begin{array}{l}\text { I feel prejudice based on } \\
\text { my race, ethnicity, and/or } \\
\text { gender when I am physically } \\
\text { active. }\end{array}$ & 419 & $1.46(.88)$ & $1.48(.94)$ & $1.42(.77)$ & .481 & .488 \\
\hline $\begin{array}{l}\text { I might experience conflict } \\
\text { with other participants } \\
\text { during physical activity. }\end{array}$ & 419 & $1.59(.91)$ & $1.60(.93)$ & $1.58(.87)$ & .049 & .826 \\
\hline
\end{tabular}

${ }^{a}$ Measured on a scale from $1=$ Strongly Disagree, $2=$ Disagree, $3=$ Neither Agree or Disagree, $4=$ Agree, $5=$ Strongly Agree across all constraint items

${ }^{b}$ For users, $\mathrm{n}=267$; for infrequent users, $\mathrm{n}=152$

$*$ Denotes statistical significance

Journal of Amateur Sport $\quad$ Volume Five, Issue Two $\quad$ Powers et al., $2019 \quad 28$


Table 3

One-Way Analysis of Variance Comparing Mean Respondent Negotiation Scores by Frequency of Use

\begin{tabular}{|c|c|c|c|c|c|c|}
\hline Negotiation Strategy $^{a}$ & $\mathbf{N}$ & $\begin{array}{l}\text { Overall } \\
\text { Mean }^{b} \\
(S D)\end{array}$ & $\begin{array}{l}\text { User } \\
\text { Mean }^{\mathrm{b}} \\
(S D)\end{array}$ & $\begin{array}{l}\text { Infrequent } \\
\text { User Mean }^{\mathrm{b}} \\
\text { (SD) }\end{array}$ & $F$ & $p$ \\
\hline Financial $(\alpha=.731)$ & 419 & $3.78(.76)$ & $3.78(.76)$ & $3.78(.78)$ & .001 & .980 \\
\hline $\begin{array}{l}\text { I try to live within my } \\
\text { means. }\end{array}$ & 418 & $3.93(.87)$ & $3.91(.86)$ & $3.95(.88)$ & .147 & .701 \\
\hline I save money. & 414 & $3.60(.97)$ & $3.63(.96)$ & $3.55(.98)$ & .745 & .389 \\
\hline I try to budget my money. & 418 & $3.81(.97)$ & $3.79(.96)$ & $3.84(.99)$ & .216 & .642 \\
\hline $\begin{array}{l}\text { Planning and Prioritization } \\
(\alpha=.790)\end{array}$ & 419 & $3.48(.59)$ & $3.63(.52)$ & $3.22(.63)$ & 53.078 & $.000 *$ \\
\hline $\begin{array}{l}\text { I try to plan ahead in order } \\
\text { to be physically active. }\end{array}$ & 419 & $3.62(.96)$ & $3.78(.87)$ & $3.33(1.04)$ & 22.385 & $.000 *$ \\
\hline $\begin{array}{l}\text { I try to improve my physical } \\
\text { activity skills. }\end{array}$ & 419 & $3.76(.94)$ & $4.00(.82)$ & $3.36(1.01)$ & 50.014 & $.000 *$ \\
\hline $\begin{array}{l}\text { I am physically active when } \\
\text { the recreation center is less } \\
\text { busy. }\end{array}$ & 412 & $3.37(1.12)$ & $3.66(.94)$ & $2.85(1.21)$ & 57.077 & $.000^{*}$ \\
\hline $\begin{array}{l}\text { I think about how import- } \\
\text { ant physical activity is. }\end{array}$ & 419 & $4.11(.80)$ & $4.20(.74)$ & $3.96(.88)$ & 9.047 & $.003 *$ \\
\hline I learn new activities. & 415 & $3.22(.83)$ & $3.25(.84)$ & $3.17(.82)$ & .843 & .359 \\
\hline $\begin{array}{l}\text { I change the location of } \\
\text { where I am physically active. }\end{array}$ & 419 & $2.74(.90)$ & $2.86(.86)$ & $2.54(.92)$ & 12.531 & $.000 *$ \\
\hline $\begin{array}{l}\text { I get up earlier or stay later } \\
\text { to have more time to be } \\
\text { physically active. }\end{array}$ & 417 & $2.95(1.17)$ & $3.20(1.11)$ & $2.52(1.16)$ & 35.244 & $.000 *$ \\
\hline $\begin{array}{l}\text { I try to prioritize my activ- } \\
\text { ities. }\end{array}$ & 419 & $4.08(.80)$ & $4.12(.76)$ & $4.01(.85)$ & 1.612 & .205 \\
\hline $\begin{array}{l}\text { Psychological Reframing } \\
(\alpha=.718)\end{array}$ & 419 & $3.42(.78)$ & $3.46(.78)$ & $3.35(.78)$ & 1.859 & .173 \\
\hline $\begin{array}{l}\text { I avoid allowing things to get } \\
\text { to me. }\end{array}$ & 416 & $3.25(.98)$ & $3.29(.99)$ & $3.17(.97)$ & 1.371 & .242 \\
\hline $\begin{array}{l}\text { I ignore what people think of } \\
\text { me. }\end{array}$ & & $3.32(1.04)$ & $3.35(1.03)$ & $3.26(1.06)$ & .811 & .368 \\
\hline $\begin{array}{l}\text { I try to ignore others bother- } \\
\text { ing me. }\end{array}$ & 416 & $3.70(.88)$ & $3.74(.89)$ & $3.62(.86)$ & 1.802 & .180 \\
\hline $\begin{array}{l}\text { I substitute a convenient activ- } \\
\text { ity over a preferred one. }\end{array}$ & 419 & $\begin{array}{l}M=3.24 \\
(.92)\end{array}$ & $3.23(.92)$ & $3.26(.92)$ & .068 & .794 \\
\hline Social $(\alpha=.805)$ & 419 & $3.13(.90)$ & $3.32(.82)$ & $2.78(.94)$ & 37.257 & $.000 *$ \\
\hline $\begin{array}{l}\text { I am physically active with } \\
\text { people like myself. }\end{array}$ & & $3.18(1.05)$ & $3.39(.92)$ & $2.80(1.15)$ & 32.879 & $.000 *$ \\
\hline
\end{tabular}


Table 3 (continued)

One-Way Analysis of Variance Comparing Mean Respondent Negotiation Scores by Frequency of Use

\begin{tabular}{|c|c|c|c|c|c|c|}
\hline Negotiation Strategy $^{a}$ & $\mathbf{N}$ & $\begin{array}{l}\text { Overall } \\
\text { Mean }^{b} \\
(S D)\end{array}$ & $\begin{array}{l}\text { User } \\
\text { Mean }^{\mathrm{b}} \\
(\text { SD) }\end{array}$ & $\begin{array}{l}\text { Infrequent } \\
\text { User Mean }^{\text {b }} \\
\text { (SD) }\end{array}$ & $F$ & $p$ \\
\hline $\begin{array}{l}\text { I try to find people with simi- } \\
\text { lar interests in physical activity. }\end{array}$ & 416 & $3.23(1.08)$ & $3.38(1.03)$ & $2.95(1.12)$ & 15.381 & $.000^{*}$ \\
\hline $\begin{array}{l}\text { I try to find people to be phys- } \\
\text { ically active with. }\end{array}$ & 417 & $2.97(1.06)$ & $3.19(1.00)$ & $2.59(1.06)$ & 33.490 & $.000^{*}$ \\
\hline $\begin{array}{l}\text { I cut short my physical ac- } \\
\text { tivity session. }\end{array}$ & 418 & $2.71(.84)$ & $2.68(.82)$ & $2.76(.88)$ & .873 & .351 \\
\hline $\begin{array}{l}\text { Recreation Center Assisted } \\
(\alpha=.591)\end{array}$ & 417 & $1.75(.70)$ & $1.89(.70)$ & $1.51(.63)$ & 30.96 & $.000 *$ \\
\hline $\begin{array}{l}\text { I talk to recreation center } \\
\text { personnel. }\end{array}$ & 416 & $1.96(.98)$ & $2.15(1.05)$ & $1.62(.91)$ & 31.557 & $.000^{*}$ \\
\hline $\begin{array}{l}\text { I arrange rides to the recre- } \\
\text { ation center with friends. }\end{array}$ & 417 & $1.66(.94)$ & $1.80(1.00)$ & $1.41(.76)$ & 17.238 & $.000^{*}$ \\
\hline $\begin{array}{l}\text { I express anger to the person } \\
\text { who caused a conflict situation } \\
\text { in the recreation center. }\end{array}$ & 416 & $1.64(.92)$ & $1.73(.97)$ & $1.50(.81)$ & 5.798 & $.016^{*}$ \\
\hline
\end{tabular}

${ }^{a}$ Measured on a scale of $1=$ Never, $2=$ Rarely, $3=$ Sometimes, $4=$ Often, $5=$ Always across all constraint items ${ }^{b}$ For users, $n=267$; for infrequent users, $n=152$

* Denotes statistical significance

entered as independent variables into a stepwise linear regression with number of respondent visits to the SRSC per month serving as the dependent variable.

The results of this stepwise regression found that two constraints and three negotiations explained a considerable $\left(R^{2}=.251, p<.001\right)$ amount of the variance in student visitation to the SRSC (Table 4; Figure 1). The Planning and Prioritizing negotiation strategy had the strongest relationship with visitation to the SRSC $(B=.423, p<.001)$. The Recreation Center Assisted negotiation strategy also had a significant positive relationship with SRSC visitation $(B=.109$, $p<.05)$. In addition, the following con- straints and negotiations all had significant negative relationships with visitation to the SRSC: Financial negotiation, Social Support constraints, and Time constraints $(B=-.136, p<.01 ; B=-.116, p<.05$; $B=-.093, p<.05$, respectively).

A second linear regression explored the constraints which were related to the negotiation strategies that predicted SRSC visitation. The Self-Efficacy and Management constraints explained a modest portion of the variance in the Planning and Prioritizing negotiation strategy $\left(R^{2}=.189, p<.001\right)$. Constraints related to Self-Efficacy had the strongest, negative relationship with SRSC visitation while Management constraints 
had a smaller, but positive relationship with SRSC visitation $(B=-.488, p<.001$; $B=.181, p<.001$, respectively). Self-Efficacy constraints also explained a small portion of the variance in Financial negotiation $\left(R^{2}=.021, \mathrm{p}<.01\right)$ and had a significant, negative relationship with Financial and Recreation Center Assisted negotiations $(B=-.145, p<.01 ; b=-.208$, $p<.01$, respectively). Lastly, constraints related to Safe Environment were positively related to Recreation Center Assisted negotiations $(B=.403, p<.001)$. Together, Safe Environment and Self-Efficacy Constraints explained a modest portion of variance in Recreation Center Assisted Negotiation strategies $\left(R^{2}=.115\right.$, $p<.001)$.

\section{Discussion}

This study sought to understand the extent to which psychosocial factors in- cluding constraints to physical activity as well as constraint negotiation strategies related to use of the SRSC among college students. The results of the study suggest that users and infrequent users of the SRSC experience constraints differently, and therefore also take different approaches to negotiating constraints.

When looking at the relationship between constraints, negotiations, and facility use, Crawford et al.'s (1991) hierarchy of intrapersonal, interpersonal, and structural constraints holds true both for frequent and infrequent users of the SRSC. That is, individuals must first move past their intrapersonal constraints in order to experience and negotiate interpersonal followed by structural constraints. Intrapersonal constraints were quite strong among respondents, specifically self-efficacy, which was negatively related to the negotiation strategies measured in this

Table 4

Final Regression Model for Constraints and Negotiations to SRSC Usage

\begin{tabular}{lclcc}
\hline Model & \multicolumn{1}{c}{$\boldsymbol{R}^{2}$} & Function & $\boldsymbol{\beta}$ & $\boldsymbol{p}$ \\
SRSC Center Usage & $.251^{* * *}$ & Planning and Prioritizing Negotiation & .423 & .000 \\
& & Financial Negotiation & -.136 & .003 \\
& & Recreation Center Assisted Negotiation & .109 & .013 \\
& & Social Support Constraint & -.116 & .014 \\
& & Time Constraint & -.093 & .041 \\
\hline Planning and Prioritiz- & $.189^{* * *}$ & Self-Efficacy Constraint & -.488 & .000 \\
ing Negotiation & & Management Constraint & .181 & .000 \\
\hline Financial Negotiation & $.021^{* *}$ & Self Efficacy Constraint & -.145 & .002 \\
\hline Recreation Center As- & $.115^{* * *}$ & Self-Efficacy Constraint & -.208 & .000 \\
sisted Negotiation & & Safe Environment Constraint & .403 & .000 \\
\hline
\end{tabular}

$* p \leq .050, * * p \leq .010, * * * p \leq .001$, Only significant variables were used in this model. 
Figure 1

Final Stepwise Multiple Linear Regression Mode

Constraints

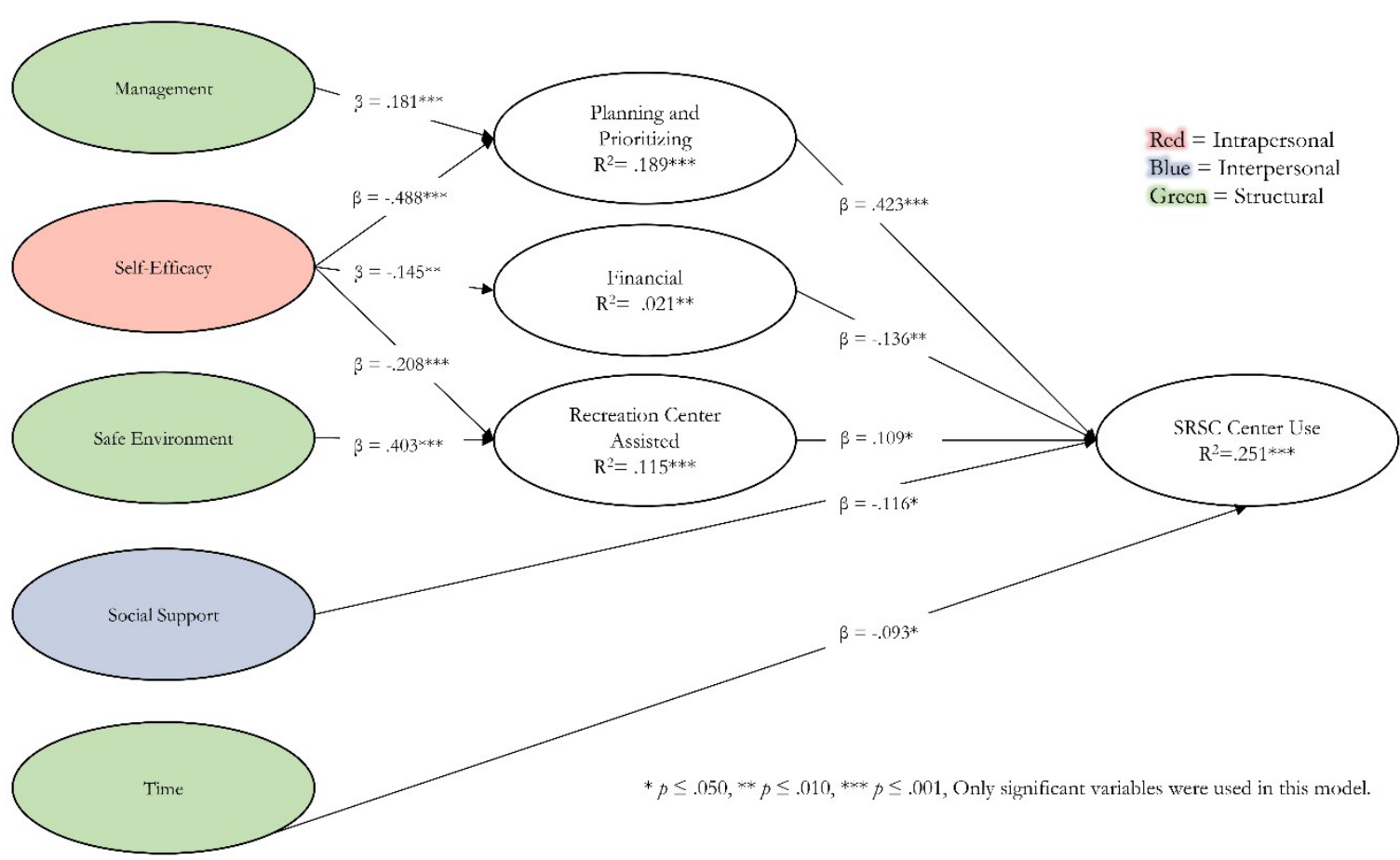

study. Those who were more constrained by self-efficacy were less likely to negotiate; however, those who did negotiate and continued through the hierarchy model were more likely to visit the SRSC more frequently. Interpersonal constraints (social support) were significantly and directly related to SRSC visitation. No negotiation strategies in this study mitigated this constraint. Infrequent users appeared to perceive stronger constraints to SRSC usage specifically in regards to a lack of social support and self-efficacy, and those who experienced these constraints were much less likely to negotiate, and therefore less likely to visit the SRSC.
When examining structural constraints for the purposes of this study, management/environment issues were examined separately from time due to the fact that time is frequently seen as major constraint to physical activity among college students, and there are limited management solutions which can address a perceived lack of time (Stankowski et al., 2017). It is interesting that those constrained by management/environment issues were more likely to negotiate in various ways, and were thus more likely to visit the SRSC more often, suggesting the importance of employing effective management strategies in these areas. 
It should be noted that this study was conducted at only one mid-size university and therefore results may not be generalizable to all SRSCs. Similar methods should be replicated elsewhere to further increase understanding of university student SRSC visitation, specifically for both frequent and infrequent user groups. Despite its limitations, this study offers some important insights to inform management of SRSCs.

\section{Management Implications}

The constraints and negotiation strategies of both user groups suggest management implications for SRSCs which could potentially increase visitation and student physical activity. We have chosen to focus our management implications in the following three areas: creating social support, supporting planning and prioritization, and supporting development of self-efficacy.

\section{Creating Social Support}

Interpersonal constraints, specifically social support, appear to be a key constraint for which students do not currently have a viable negotiation strategy. Improving social support systems at the SRSC should be a focus of campus recreational sport professionals. SRSCs should focus on creating a welcoming environment for all users. Throughout the SRSC, visitors should see people engaging in a variety of diverse activities, not just weight lifting or use of exercise machines. In addition to considering the atmosphere throughout the center, SRSC managers should focus on the entrance to the facility and what people see when they first enter. SRSCs should be perceived as more than just a gym or fitness center, and diversifying activity offerings to appeal to a wide-array of potential users may help meet this goal.

SRSCs should consider hosting orientation programs for all students and particularly focus on engaging students in their first year. SRSCs could host Freshman orientation programs within their facilities or partner with other orientation programs to bring students into the SRSC to learn how to enter the facility, see what is available, and try out various activities and types of equipment. Additionally, through partnerships with residence halls, SRSCs could create point system participation incentives such as what is done with some intramural sport programs. These strategies could help students explore the SRSC with their peers and potentially create a more extensive network of people with whom to be physically active.

For some segment of the student population, a satellite program could get them to use student campus recreation services, even if they are in a different location. Through residence hall partnerships, SRSCs could capitalize on intact communities through moving programming to the residence halls or creating satellite fitness facilities in residence halls managed by campus recreation. It may be important to help certain segments of students overcome constraints by taking programs and facilities to them. In 
this way, students may be able to engage in meaningful and structured sport and physical activity, regardless of where that activity is taking place.

As Hartman et al. (2018) suggested, partnerships between SRSCs and other campus entities can help to address health and wellness outcomes through pooling resources and minimizing the duplication of services. For example, at the University of Vermont (2019), the Wellness Environment program is a collaboration between residence life, an academic course, and campus recreation. Wellness Environment designated residence halls provide incentives for students to engage in and develop healthy habits. Students living in these halls have a required course during their first semester and also have access to in-house fitness centers with ample fitness equipment and programming focusing on both physical and mental health (University of Vermont, 2019).

Other universities have even merged their campus recreation and wellness centers or integrated wellness programming into their SRSC. For example, in addition to providing fitness facilities and recreational sports programming, Elon University's (2019) Campus Recreation and Wellness department provides holistic health programs, substance use education, and trains student leadership to promote on-campus health and wellbeing. Additionally, beginning this past year, the University of New Hampshire (2019) has integrated office/programming space in their SRSC for a health and wellness satellite location. The health and wellness office maintains close partnerships with the university's psychological and counseling services to address mental health concerns among students (University of New Hampshire, 2019). NIRSA: Leaders in Collegiate Recreation (2018) has additional resources and examples of successful campus partnerships for health and wellbeing across the country. In addition, institutions such as Missouri Southern State University, University of Colorado-Denver, South Dakota State University, and the University of $\mathrm{Ne}$ vada-Las Vegas have all engaged in collaborative partnerships linking together student health, wellness, nutrition, recreation, and sport (Fullerton, 2011).

Moreover, SRSCs have an opportunity to develop non-traditional programming. For example, at Utah State University (2018), the student gaming team (a club sport) is housed with the campus recreational sports program. Not only does this get students exposed to the SRSC and other club sports, but also gets members in an area surrounded by people engaging in physical activity. Encouraging student groups and organizations to meet within the SRSC may help to get infrequent users into the facility to expose them to the various opportunities that are happening within.

\section{Supporting Planning and Prioritization}

Planning and Prioritization was one of the most notable negotiation strategies used by respondents in this study, 
especially for those constrained by management issues. SRSCs can expand assistance to students by providing ways for people to plan ahead and prioritize time to be physically active in the SRSC. For example, universities should consider using credit-based courses to help students gain experience incorporating physical activity into their daily schedule. Examples include the Leisure Skills Program at Clemson University and the Lifetime Activity Program at the University of New Hampshire. Moreover, some universities have implemented peer wellness education programs. For example, at the University of Iowa (2017), the student wellness center has student employees who help other students to plan and engage in health behaviors, one of which is physical activity. For those without experience planning and prioritizing health behaviors, scheduled academic courses or peer mentoring programs of this type may be helpful.

In addition, SRSCs should consider which locations for programs and facilities are most accessible to students. Decentralization of SRSCs (for example, into residence halls or satellite facilities) may be more effective than having one large central facility, particularly if transportation is a barrier to visitation. Managers should also consider how students travel to SRSCs; if limited parking is a barrier, there may be an opportunity to promote alternative forms of transportation or use various technologies (i.e. cameras, car count) to inform students of how full the parking lot is.
Furthermore, SRSCs should continue promoting the accessibility of their facilities and programs. SRSCs can utilize mobile technologies which allow students to access real-time information on crowding, available equipment or rooms, and the best times to access the SRSC. This could be accomplished through communicating the number of current users as compared to the capacity of the facility (for example, with student ID card swipe data) or utilizing low-resolution cameras which help students to identify areas or equipment which is not currently in use without providing enough detail to identify users. SRSCs could also utilize personnel to count the number of available machines, rooms, etc. and mark them on an SRSC map on a regular schedule and give real-time updates to students (e.g., updated notifications every 30 minutes). These strategies may be especially useful in encouraging planning and prioritization among students who are constrained by management issues such as crowding or lack of available equipment.

\section{Supporting Development of Self- Efficacy}

The results of this study provide support for management actions which help to limit structural and interpersonal constraints. These constraints are more readily influenced by the way in which SRSCs are managed, and thus should be addressed first. Perhaps elimination of structural and interpersonal barriers would allow more opportunities for students to address their intrapersonal 
constraints. SRSCs have opportunities to help students build self-efficacy in physical activity. For example, offering credit-based courses (see the examples above) that promote participation and are barrier-free (e.g., all equipment is provided) could help students build competence at the introductory level. Students are used to entering introductory classes on subjects which they have no prior knowledge. Utilizing credit-based alternatives to feed SRSC participation at the instructional level may be helpful for encouraging introductory skill development and building self-efficacy.

\section{Conclusion}

SRSCs provide many opportunities for physical activity which can benefit students' physical and mental health. Given current health among college students, it is important to understand constraints to physical activity at SRSCs as well as negotiation strategies which students use to increase their visitation to SRSCs. Findings of this study demonstrated differences in constraints and negotiations between users and infrequent users and highlighted the importance of social support and self-efficacy constraints as well as students' experiences utilizing prioritization and planning negotiation strategies. Through management actions which address these factors, SRSCs can work towards increasing student visitation, particularly among infrequent users.

\section{References}

American College Health Association. (2016). National College Health Assessment: Executive Summary. Retrieved from http://www.acha-ncha. org/reports_ACHA-NCHAIIc.html American College Health Association. (2016). National College Health Assessment: Full Report. Retrieved from http://www.acha-ncha.org/reports_ ACHA-NCHAIIc.html

Arnett, J. J. (2014). Adolescence and emerging adulthood. Boston, MA: Pearson.

Bland, H. W., Melton, B. F., Bigham, L. E., \& Welle, P. D. (2014). Quantifying the impact of physical activity on stress tolerance in college students. College Student Journal, 48(4), 559-568, http://dx.doi.org/10.1123/ rsj.2014-0046

Centers for Disease Control and Prevention (2017). Current physical activity guidelines: Key guidelines for adults. Retrieved from https://www. cdc.gov/cancer/dcpc/prevention/ policies_practices/physical_activity/ guidelines.htm

Crawford, D. W., Jackson, E. L., \& Godbey, G. (1991). A hierarchical model of leisure constraints. Leisure Sciences, 13, 309-320, doi:10.1080/01490409109513147

Danbert, S. J., Pivarnik, J. M., McNeil, R. N., \& Washington, I. J. (2014). Academic success and retention: The role of recreational sports fitness facilities. Recreational Sports Journal, 38(1), 14-22, http://dx.doi.org/10.1123/ rsj.2013-0010 
DeVellis, R.F. (1991). Scale development. Newbury Park, NJ: Sage Publications. Dillman, D. A., Smyth, J. D., \& Christian, L. M. (2009). Internet, mail, and mixed-mode surveys: The tailored design method. Hoboken: Wiley.

Elkins, D. J., Beggs, B. A., \& Choutka, E. (2007). The contribution of constraint negotiation to the leisure satisfaction of college students in campus recreational sports. Recreational Sports Journal, 31(2), 107-118, https://doi. org/10.1123/rsj.31.2.107

Elon University. (2019). Campus recreation \& wellness. Retrieved from https://www.elon.edu/u/campus-recreation-wellness/

Flood, J. P., \& Parker, C. (2014). Student awareness of university adventure programs: Understanding motivations and constraints. Recreational Sports Journal, 38(2), 104-117, https://doi. org/10.1123/rsj.2013-0021

Forrester, S. (2015). Benefits of collegiate recreational sports participation: Results from the 2013 NASPA assessment and knowledge consortium study. Recreational Sports Journal, 39(1), 2-15, https://doi.org/10.1123/ rsj.2015-0005

Fullerton, D.S. (2011). A collaborative approach to college and university student health and wellness. New Directions for Higher Education, 2011(153), 61-69, https://doi.org/10.1002/ he. 427

Hall, D.A. (2006). Participation in a campus recreation program and its effect on student retention. Recreational
Sports Journal, 30(1), 40-45, https:// doi.org/10.1123/rsj.30.1.40

Hartman, C. L., Evans, K. E., Barcelona, R. J., \& Brookover, R. S. (2018). Constraints and facilitators to developing collaborative campus wellness partnerships. Recreational Sports Journal, 42(2), 130-144, https://doi. org/10.1123/rsj.2017-0030

Huesman Jr., R. L., Brown, A. K., Lee, G., Kellogg, J. P., \& Radcliffe, P. M. (2009). Gym bags and mortarboards: Is use of campus recreation facilities related to student success? NASPA Journal, 46(1), 50-71, doi:10.2202/1949-6605.5005

Jackson, E. L., Crawford, D., \& Godbey, G. (1993). Negotiation of leisure constraints. Leisure Sciences, 15, 1-12, https://doi. org/10.1080/01490409309513182

Kampf, S., \& Teske, E. J. (2013). Collegiate recreation participation and retention. Recreational Sports Journal, 37(2), 85-96, https://doi. org $/ 10.1123 / \mathrm{rsj} .37 .2 .85$

Kim, K. R., Sparvero, E. S., \& Olmeda, N. (2016). Benefits of Campus Recreational Sports: A Rasch Calibration. Recreational Sports Journal, 40(2), 165-178, https://doi.org/10.1123/ rsj.2015-0047

Nelson, M. C., Story, M., Larson, N. I., Neumark-Sztainer, D., \& Lytle, L. A. (2008). Emerging adulthood and college-aged youth: An overlooked age for weight-related behavior change. Obesity, 16(10), 2205-2211, https:/ / doi.org/10.1038/oby.2008.365 
NIRSA: Leaders in Collegiate Recreation (2018). Campus collaborations \& partnerships. Retrieved from https:// nirsa.net/nirsa/portfolio-items/ health-and-wellbeing-collaborations-partnerships/

Racette, S. B., Deusinger, S. S., Strube, M. J., Highstein, G. R., \& Deusinger, R. H. (2008). Changes in weight and health behaviors from freshman through senior year of college. Journal of Nutrition Education and Behavior, 40(1), 39-42, https:/ / doi. org/10.1016/j.jneb.2007.01.001 Small, M., Bailey-Davis, L., Morgan, N., \& Maggs, J. (2013). Changes in eating and physical activity behaviors across seven semesters of college: Living on or off campus matters. Health Education \& Behavior, 40(4), 435-441, https:/ /doi. org/10.1177/1090198112467801

Son, J. S., Mowen, A. J., \& Kerstetter, D. L. (2008). Testing alternative leisure constraint negotiation models: An extension of Hubbard and Mannell's study. Leisure Sciences, 30(3), 198-216, https://doi. org/10.1080/01490400802017308 Stankowski, C. L., Trauntvein, N. E., \& Hall, S. L. (2017). I use the student recreation center, but I would use it More if...: Understanding male and female constraints to student recreation center use. Recreational Sports Journal, 41(1), 55-66, https://doi. org/10.1123/rsj.2015-0026

University of Iowa. (2017). Peer wellness educators. Retrieved from https:// www.studentwellness.iastate.edu/ peer-education/

University of New Hampshire (2019). Health \& wellness. Retrieved from https://www.unh.edu/health/welcome

University of Vermont. (2019). Wellness environment. Retrieved from https:// www.uvm.edu/we

Utah State University. (2018). Campus recreation: Esports. Retrieved from https://www.usu.edu/campusrec/ club_sports/esport

VanKim, N. A., \& Nelson, T. F. (2013). Vigorous physical activity, mental health, perceived stress, and socializing among college students. American Journal of Health Promotion, 28(1), 7-15, https://doi.org/10.4278/ ajhp.111101-QUAN-395

Young, S. J., Ross, C. M., \& Barcelona, R. J. (2003). Perceived constraints by college students to participation in campus recreational sports programs. Recreational Sports Journal, 27(2), 47-62, https://doi.org/10.1123/rsj.27.2.47 